\title{
Studi Sifat Mekanik Re-casted Ingot A356 Produksi PT. INALUM Dengan Menggunakan Cooling Slope
}

\author{
Tugiman $^{1 *}$, Husni Mubaroh ${ }^{2}$, Adi Chandra ${ }^{3}$, Qory Fauzan ${ }^{4}$, Satria Lasmana $^{5}$ \\ 1,2,3,4,5 Departemen Teknik Mesin, Fakultas Teknik, Universitas Sumatera Utara \\ Jl. Almamater Kampus Padang Bulan, Medan, 20155, Indonesia \\ * Penulis korespondensi; E-mail: tugiman.karmani@gmail.com
}

\begin{abstract}
ABSTRAK
Alumunium (Al) A356 yang memiliki sifat mekanis yang baik telah secara luas dipergunakan di bidang teknik. Namun tidak dapat dihindari bahwa proses pengecoran ulang bahan Al termasuk A356 akan menurunkan sifat mekanis. Usaha perbaikan dan meminimalkan pengaruh tersebut telah dilakukan dengan berbagai cara diantaranya dengan menggunakan cooling slope. Penelitian ini bertujuan untuk mengetahui sifat mekanis dan mikrostruktur pengecoran ulang aluminium A356 yang dilengkapi dengan cooling slope. Proses penuangan dilakukan pada temperatur $680^{\circ} \mathrm{C}$ pada berbagai kemiringan pelat yaitu $30^{\circ}, 45^{\circ}$ dan $60^{\circ}$. Pelat yang digunakan terbuat dari bahan mild steel dengan panjang $80 \mathrm{~cm}$ diletakkan diatas cetakan permanen. Pengamatan struktur mikro menggunakan mikroskop optik memperlihatkan mikrostruktur terdiri dari primary $\mathrm{Al}$ dan partikel silikon. Lebih lanjut, sangat jelas terlihat bahwa variasi kemiringan pelat pada saat penuangan sangat berpengaruh terhadap kehalusan mikrostruktur. Hasil pengujian kekerasan metode Brinell diperoleh nilai tertinggi sebesar 62 BHN pada variasi sudut tuang $30^{\circ}$. Pengujian ketahanan aus menggunakan metode pin on disk dilakukan terhadap sampel coran, hasilnya diperoleh laju keausan paling rendah pada bahan dengan sudut kemiringan $30^{\circ}$ dan tertinggi pada sudut $60^{\circ}$. pengujian tarik telah dilakukan pada suhu ruang, kekuatan tarik maksimum adalah $157 \mathrm{MPa}$ diperoleh untuk sampel paduan alumunium dengan sudut cooling slope $30^{\circ}$.
\end{abstract}

Kata kunci: Sifat mekanis; aluminium A356; cooling slope; kekerasan.

\section{ABSTRACT}

A356 Aluminum alloys have been widely used in the engineering field due to their good mechanical properties. However, re-casted of aluminum alloys such as A356 cause a decrease in the mechanical properties.The effort of researchers to improve and minimize the negative effect of this process has been done with varying methods such as cooling slope. The aims of this current research to investigate the mechanical properties and microstructure of the re-casted of the A356 aluminum alloy which has a cooling slope. Pouring processes were carried out at $680^{\circ} \mathrm{C}$ with varying angles $\left(30^{\circ}, 45^{\circ}\right.$, and $\left.60^{\circ}\right)$ of the plate of cooling. The $80 \mathrm{~cm}$ length of mild steel plate have been used in this cooling slope and it installed near above of permanent mold. Microstructure observation was conducted by optical microscopy (OM), the result shows the microstructure consists of primary $\mathrm{Al}$ and silicon particles. Furthermore, it is clear that the angles of the plate at pouring processes strongly influence the microstructure refinement. The highest hardness of the re-casted A356 alloy is $62 \mathrm{BHN}$ obtained for $30^{\circ}$ of theangle. The wear resistance test of re-casted A356 alloy was conducted by using pin on disc method, the result shows that the lowest wear phenomenon occurred for $30^{\circ}$ of plate angle, on the contrary, the maximum wear was obtained for $60^{\circ}$ of angle. The tensile test was carried out at room temperature which is the highest strength about 157 MPa obtained for the aluminum alloy with $30^{\circ}$ of cooling slope angle.

Keywords: Mechanical properties; aluminum A356; cooling slope; hardness.

\section{PENDAHULUAN}

Aluminium merupakan material yang sangat menjanjikan untuk penggunaan di bidang teknik dikarenakan keuletan, penghantar panas dan ketahanan korosi yang baik. Namun dengan struktur kristal face center cubic ( $f c c$ ) bahan ini juga dikenal memiliki sifat mekanis yang relatif rendah sehingga memiliki keterbatasan bila dibandingkan dengan bahan teknik lain seperti baja. Khususnya A356 merupakan bahan yang memiliki sifat mekanis cukup baik dengan elemen alloy utama silikon yang sangat cocok untuk aplikasi pada bagian-bagian komponen mesin. Penggunaan paduan Al-Si alloy 
yang luas mendorong peneliti untuk terus mengembangkan bahan tersebut untuk mendapatkan karakteristik yang sesuai. Usaha perbaikan sifat mekanis ini telah dilakukan dengan berbagai cara seperti perlakuan panas [1], pengerasan regang [2], panambahan atau pemilihan elemen alloy yang bisa meningkatkan kekuatan [3,4], dan partikel pemerkuat seperti karbida ataupun oxide [5,6]. Berbagai cara yang telah dilakukan tersebut tentunya memiliki kelebihan dan kekurangan seperti penurunan keuletan [2], koefesion ekspansi thermal [4], dan kekuatan tarik pada penambahan partikel oxide/ $\mathrm{Y}_{2} \mathrm{O}_{3}$ (3.0 mass\%) [6] sehingga peluang untuk perbaikan sifat mekanis material khususnya $\mathrm{Al}$ masih terbuka luas. Lebih lanjut, modifikasi struktur mikro merupakan hal sangat penting dalam perbaikan karakteristik alumunium. Ukuran, bentuk, dan distribusi butir sangat erat hubungannya dengan kekuatan bahan. Modifikasi mikrostruktur khususnya ukuran butir dapat dilakukan melalui berbagai cara diantaranya pengaturan pendinginan. Laju pendinginan yang merupakan faktor penting yang mempengaruhi sifat mekanis seperti kekuatan tarik bahan alumunium 2A14 [7], pengintian dan ukuran butir paduan $\mathrm{Mg}-\mathrm{Al}-\mathrm{Zn}$ [8]. Proses penghalusan mikrostruktur dalam rangka memperbaiki sifat mekanis dapat dilakukan dengan berbagai metode seperti penggunaan twin-screw untuk memperoleh intensive melt shearing dari alumunium alloy [9] dan cooling slope [10]. Penghalusan struktur primary Al dan Si dapat diperoleh melalui metode ultrasonic melt [11]. Aplikasi cooling slope telah dilakukan pada berbagai jenis paduan seperti 7075 wrought aluminum [12], A380 alloy [13], Al-Si-Mg alloy[14], dan Alumunium A356 [15]. Penerapan cooling slope pada saat penuangan cairan aluminium merupakan metode yang potensial untuk modifikasi struktur mikro. Pada penelitian sebelumnya telah disampaikan bahwa penggunaan pelat miring pada penuangan A356 mempengaruhi laju perpindahan panas, proses pengintian dan penghalusan butir [16]. Selain penghalusan butir, metode ini juga mempengaruhi pembentukan butir a-Al yang berbentuk spherical pada bahan alumunium A356 [17]. Metode cooling slope juga bisa digunakan sebagai usaha untuk mengurangi segregasi dan pembentukan porositas pada produk coran [18].

Berdasarkan uraian dari penelitian terdahulu jelas terlihat bahwa metode cooling slope sangat potensial digunakan untuk memodifikasi bentuk dan ukuran mikrostruktur paduan Al. Pada bagian lain, permasalahan yang berkaitan dengan penurunan sifat mekanis sering ditemukan pada pengecoran ulang paduan alumunium. Usaha mengatasi permasalahan tersebut penting dilakukan, sehingga dilakukan penelitian mengenai penerapan cooling slope untuk memperkaya data sifat mekanis bahan $\mathrm{Al}$ yang dicor ulang. Penelitian ini bertujuan menginvestigasi pengaruh penerapan model cooling slope pada saat penuangan terhadap mikrostruktur dan sifat mekanis ingot A356 produksi PT.INALUM yang dilakukan proses re-casted menggunakan pengecoran gravitasi.

\section{METODOLOGI PENELITIAN}

Pada penelitian ini digunakan alumunium A356 produksi lokal dari PT. INALUM, komposisi bahan ingot alumunium terdiri dari $\mathrm{Al}(92,49 \%), \mathrm{Si}(6,90 \%)$, $\mathrm{Fe}(0.11 \%)$, Ti (0,14\%), Mg (0.34\%, dan $\mathrm{Sr}(0,020 \%)$. Pengecoran ulang (re-casted) dilakukan dengan menggunakan cooling slope pada saat penuangan ke dalam cetakan permanen yang terbuat dari bahan mild steel, penuangan cairan alumunium dilakukan pada suhu $680^{\circ} \mathrm{C}$. Kemiringan pelat yang digunakan $30^{\circ}$, $45^{\circ}$, dan $60^{\circ}$ yang dilengkapi dengan sistem pendingin circulation water pada bagian bawah pelat. Susunan peralatan cooling slope dan proses penuangan seperti pada gambar 1a dan 1b. Karakterisasi bahan hasil coran dilakukan dengan berbagai cara, diantaranya observasi mikrostruktur. Pengamatan mikrostruktur dilaksanakan menggunakan Reflected Metallurgical Microscope dengan pembesaran 100x. Pengujian kekerasan standar Brinnel terhadap sampel coran menggunakan beban sebesar 500 Kgf dengan durasi penekanan $5 \sim 10$ detik. Ketahanan aus masing-masing sampel diperoleh melalui pengujian menggunakan metode pin on disc test (ASTM G99-04), dimana bahan pin memiliki kekerasan yang lebih tinggi dari sampel uji alumunium yang berbentuk disc. Pengujian keausan ini dilakukan pada kondisi kering tanpa pelumas dan dilakukan pada kondisi suhu kamar yaitu $30^{\circ} \mathrm{C}$ hingga $33^{\circ} \mathrm{C}$. Beban yang digunakan pada pengujian ini sebesar 5 $\mathrm{N}$ dan variasi kecepatan pada $150 \mathrm{rpm}, 180 \mathrm{rpm}$, dan 210 rpm masing-masing dilakukan selama 30 detik.

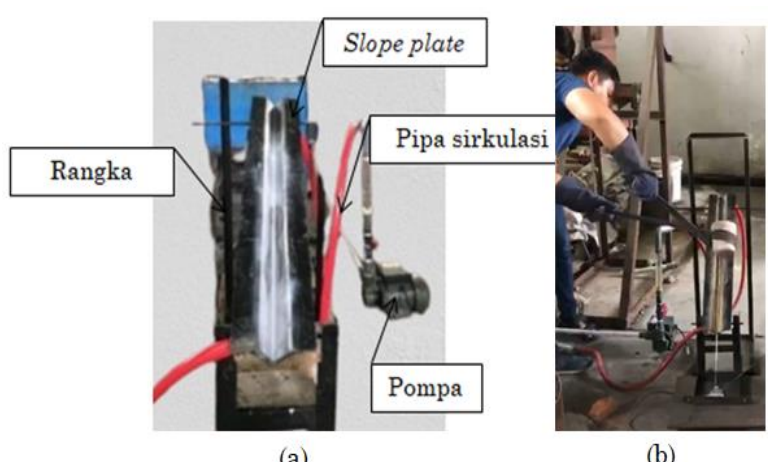

Gambar 1. (a) Skema peralatan cooling slope dan (b) proses penuangan

Selanjutnya pengujian tarik terhadap sampel dilakukan untuk mengetahui kekuatan bahan. Sampel pengujian tersebut berbentuk pelat dengan dimensi berpedoman kepada standar ASTM E8 dengan dimensi sampel seperti ditampilkan pada tabel 1. Gambar sampel uji tarik diperlihatkan pada gambar 2. Sampel uji tarik dipersiapkan secara teliti 
menggunakan mesin sekrap sehingga memenuhi ukuran standar sesuai ASTM E8 tersebut. Selanjutnya photo makro diambil pada permukaan sampel untuk melihat karakteristik patahan setelah pengujian. Preparasi sampel untuk photo mikrostruktur diawali dengan proses pengamplasan dengan kertas ukuran mesh 100 hingga 1200, dilanjutkan proses polishing dengan bantuan autosol untuk mendapatkan permukaan sampel yang halus.

Tabel 1. Dimensi ASTM E8 untuk sampel tipe pelat

\begin{tabular}{c|c}
\hline Bagian & Dimensi (mm) \\
\hline L (Length) & 200 \\
T (Thickness) & 6 \\
B (Length Of Grip Section) & 50 \\
A (Length Of Reduced Section) & 57 \\
C (Width Of Grip Section) & 20 \\
W (Width) & 6 \\
R (Radius) & 12,5 \\
\hline
\end{tabular}

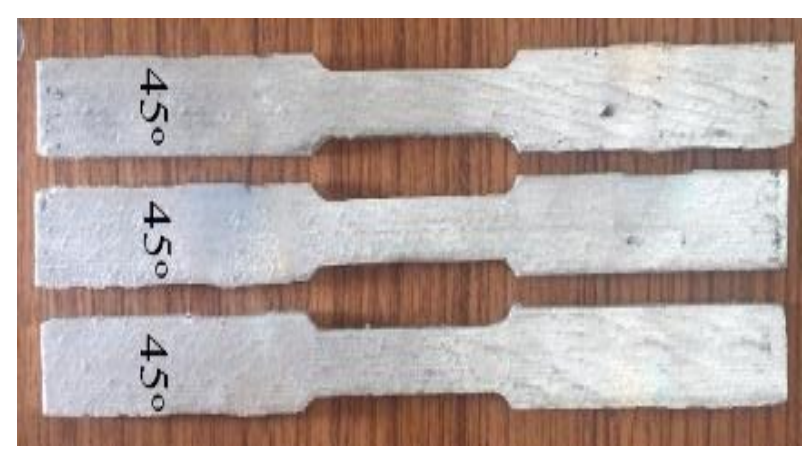

Gambar 2. Contoh sampel uji tarik tipe pelat untuk sudut kemiringan $45^{\circ}$

\section{HASIL DAN PEMBAHASAN}

\section{Analisa mikrostruktur}

Gambar 3 memperlihatkan hasil pengujian optical microscope (OM) untuk empat sampel aluminium A356 dan tiga sudut kemiringan. Gambar 3a merupakan mikrostruktur sampel ingot $\mathrm{Al}$ (as-cast) hasil pengamatan dimana tersusun atas primary $\mathrm{Al}$ berwarna terang dan partikel silikon berwarna gelap. Ukuran butir utama $\mathrm{Al}$ terlihat cukup besar dengan partikel silikon menempati area antara butir yang juga membentuk cluster/kelompok. Proses re-casted menggunakan kemiringan sudut $30^{\circ}$ menyebabkan perubahan mikrostuktur, lihat gambar 3b. Mikrostruktur yang lebih halus serta distribusi Si yang lebih homogen diperoleh pada sampel tersebut. Pada bagian lain peningkatan sudut kemiringan $45^{\circ}$ dan $60^{\circ}$ secara jelas mempengaruhi perubahan struktur mikro seperti ukuran butir yang lebih kasar dan pembentukan porositas seperti diperlihatkan pada gambar 3c dan 3d. Secara umum dapat disimpulkan bahwa hasil pengamatan menggunakan OM terlihat bahwa struktur butir merupakan non columnar, dimana butir tersusun secara tidak konsisten atau tidak beraturan.
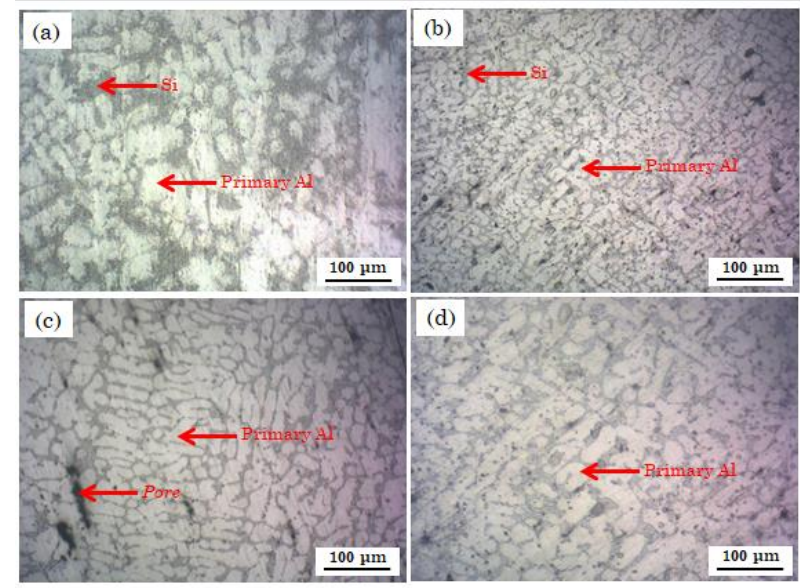

Gambar 3. Microstruktur alumunium A356 dengan variasi sudut penuangan: (a) as cast, (b) $30^{\circ}$, (c) $45^{\circ}$, dan (d) $60^{\circ}$.

Kondisi butir seperti ini kemungkinan diakibatkan oleh laju pendinginan yang tidak seragam selama proses solidifikasi, adanya pengotor yang terdispersi ke dalam cairan $\mathrm{Al}$ selama proses penuangan dan lokasi pengambilan sampel uji juga mempengaruhi bentuk struktur butir. Keberadaan pengotor dan gas-gas yang terperangkap pada cairan $\mathrm{Al}$ sebisa mungkin dihindarkan karena akan mempengaruhi terbentuknya porositas maupun kemungkinan segregasi elemen pada mikrostruktur. Beberapa kontaminan seperti oksida dan karbon (nonmetallic) ditemukan juga pada coran paduan alumunium-silikon [19].

\section{Hasil pengujian sifat mekanis}

Gambar 4 memperlihatkan hasil pengujian kekerasan bahan re-casted A356 menggunakan teknik cooling slope pada berbagai kemiringan. Kekerasan maksimum $62,1 \mathrm{BHN}$ dan terendah $56,3 \mathrm{BHN}$, Nilai kekerasan tersebut masing-masing diperoleh untuk penggunaan cooling slope dengan kemiringan $30^{\circ}$ dan $60^{\circ}$. Hasil pengujian kekerasan memperlihatkan bahwa kekerasan yang dihasilkan dipengaruhi oleh sudut cooling slope. Jika dibandingkan dengan kekerasan ingot (as-cast) yang memiliki kekerasan 49,8 BHN maka perbaikan kekerasan melalui modifikasi re-casted $\mathrm{Al} 356$ dapat meningkatkan kekerasan bahan paduan Alumunium. Pada penelitian paduan $\mathrm{Al}-\mathrm{Si}$ ini, peningkatan kekerasan maksimum sebesar $24,6 \%$ diperoleh pada sudut kemiringan pelat $30^{\circ}$ dibandingkan dengan kondisi as-cast. Kemiringan yang kecil (30) akan menghasilkan laju aliran lebih lambat memasuki cetakan sehingga mempengaruhi proses pengintian dan besar butir primary $\mathrm{Al}$ dan distribusi silikon. Butiran yang lebih halus dengan distribusi yang lebih homogen pada bahan coran menghasilkan kekerasan yang lebih baik yaitu 62,1 BHN, 60,6 BHN, dan 56,3 BHN lebih tinggi bila dibandingkan A356 as cast sebesar 49,8 BHN. Penelitian sebelumnya telah melaporkan bahwa butir alumunium yang lebih kecil menghasilkan 
kekerasan yang lebih tinggi [20]. Distribusi yang homogen dan bentuk dari butir primary $\mathrm{Al}$ dapat diperoleh melalui pengaturan laju pendinginan dan modifikasi slurry [21]. Hasil pengujian kekerasan (gambar 4) memperlihatkan nilai yang berkesesuaian dengan pengamatan mikrostruktur pada Gambar 3.

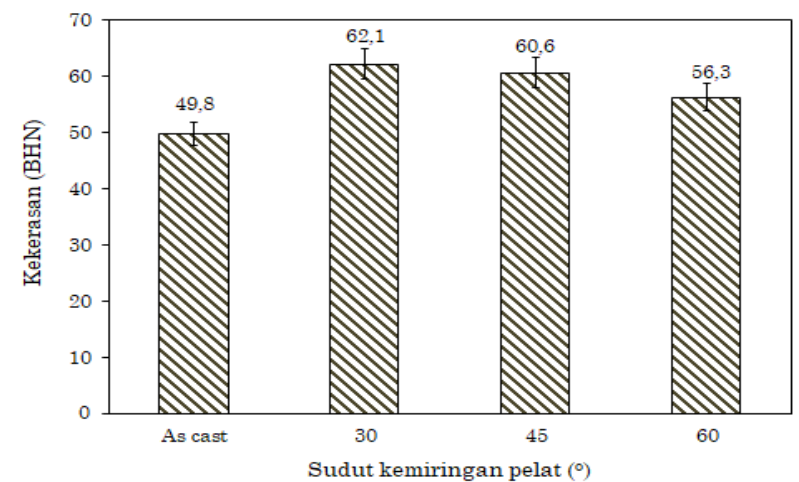

Gambar 4. Hubungan antara kemiringan cooling slope terhadap kekerasan bahan re-casted A356.

Pengujian ketahanan aus dilakukan terhadap bahan re-casted A356 menggunakan metode pin on disk pada berbagai kecepatan putaran disk, hasil pengujian aus dinyatkan dalam bentuk hubungan kecepatan terhadap laju keausan dalam satuan $\mathrm{mm}^{3} / \mathrm{s}$ seperti diperlihatkan pada Gambar 5. Laju keausan tertinggi adalah $2,78 \mathrm{~mm}^{3} / \mathrm{s}$ diperoleh pada putaran 210 rpm untuk bahan re-casted A356 yang dilengkapi cooling slope dengan sudut penuangan $60^{\circ}$. Hasil ini berkesuain dengan nilai kekerasan yang diperlihatkan pada gambar 4. Sebaliknya, laju keausan terendah sebesar $1,44 \mathrm{~mm}^{3} / \mathrm{s}$ diperoleh pada bahan re-casted dengan kemiringan slope $30^{\circ}$ yang memiliki kekerasan tertinggi. Hasil pengujian keausan yang diperoleh terlihat bahwa peningkatan kecepatan menyebabkan laju keausan semakin cepat. Hal ini kemungkinan berkaitan dengan kecepatan yang tinggi akan menghasilkan panas yang lebih tinggi terjadi antara pin dan disk alumunium. Kenaikan temperatur yang terjadi selama proses pengujian aus pada akhirnya akan menurunkan kekerasan permukaan sampel paduan Alumunium. Lebih lanjut, profil bekas lintasan hasil uji aus diperlihatkan gambar 6. Gambar 6a dan 6b merupakan bentuk lintasan hasil pengujian aus untuk sampel dengan kemiringan pelat $30^{\circ}$, gambar tersebut memperlihatkan lebar lintasan dan kedalaman lebih kecil bila dibandingkan dengan kemiringan $60^{\circ}$, lihat gambar 6c dan 6d. Bentuk dan ukuran lintasan uji aus sangat berkaitan dengan permukaan material yang hilang diakibatkan oleh beban pin yang diberikan selama proses pengujian. Laju keausan terbesar dialami sampel yang menggunakan cooling slope dengan sudut $60^{\circ}$, hal ini ditandai dengan lintasan uji aus yang lebih lebar dan dalam diperoleh dari pengamatan menggunakan mikroskop optik. Hasil pengamatan profil lintasan uji aus pada gambar 6 telah mengkonfirmasi laju keausan hasil perhitungan untuk dua buah sampel dengan sudut pelat $30^{\circ}$ dan $60^{\circ}$ yang diperlihatkan pada gambar 5 . Sebagai tambahan, profil kedalaman lintasan uji aus tidak sepenuhnya berbentuk setengah bola yang sempurna. Faktor yang memengaruhi bentuk lintasan berkaitan dengan adanya getaran yang terjadi akibat pembebanan dan kondisi pin dengan ujung berbentuk bola tidak sempurna.

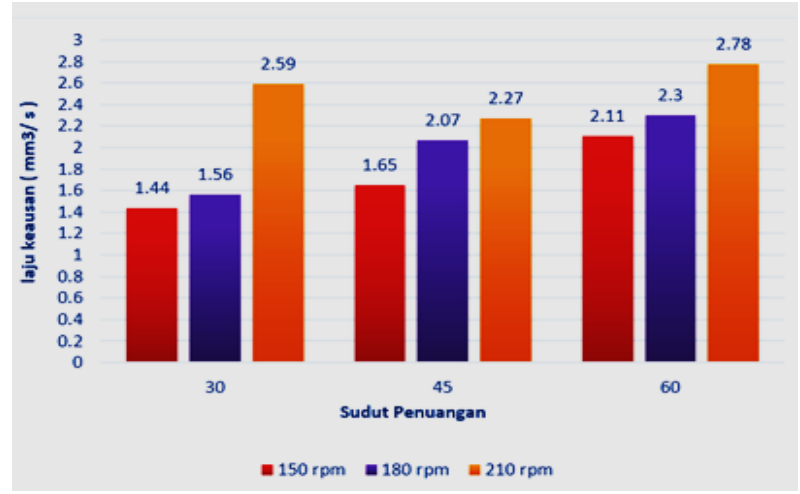

Gambar 5. Hubungan antara kemiringan cooling slope terhadap laju keausan bahan re-casted A356 pada berbagai kecepatan disk.
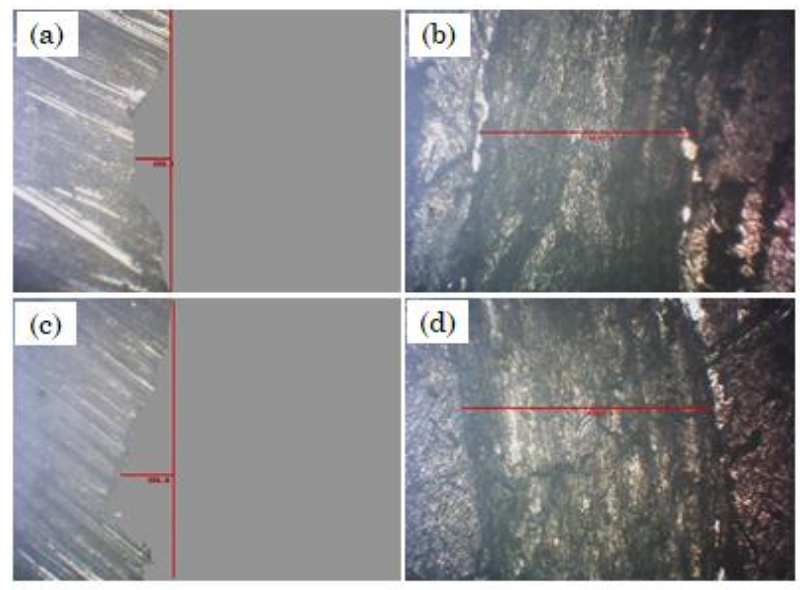

Gambar 6. Lebar dan kedalaman bekas goresan uji aus dengan sudut yang berbeda: (a-b) $30^{\circ}$ dan (c-d) sudut $60^{\circ}$ dengan kecepatan disk $150 \mathrm{Rpm}$.

Gambar 7 memperlihatkan hasil pengujian kekuatan tarik pada sampel dengan berbagai kemiringan cooling slope. Kekuatan tarik maksimum sebesar $158 \mathrm{MPa}$ diperoleh pada sampel dengan kemiringan slope $30^{\circ}$. Mickostruktur yang lebih halus dengan distribusi homogen akan mempengaruhi gerakan dislokasi pada sampel uji tarik, sehingga pada akhirnya akan meningkatkan kekuatan tarik suatu bahan. Keberadaan porositas seperti yang terlihat pada sampel yang memiliki kemiringan cooling slope $45^{\circ}$ (lihat gambar 1b) tidak diragukan lagi akan menurunkan kekuatan bahan, seperti diperlihatkan hasil uji tarik pada gambar 7. Secara umum kekuatan tarik sampel re-casted berkesesuaian dengan pengujian mekanis lainnya serta mikrostruktur pada gambar 3. 


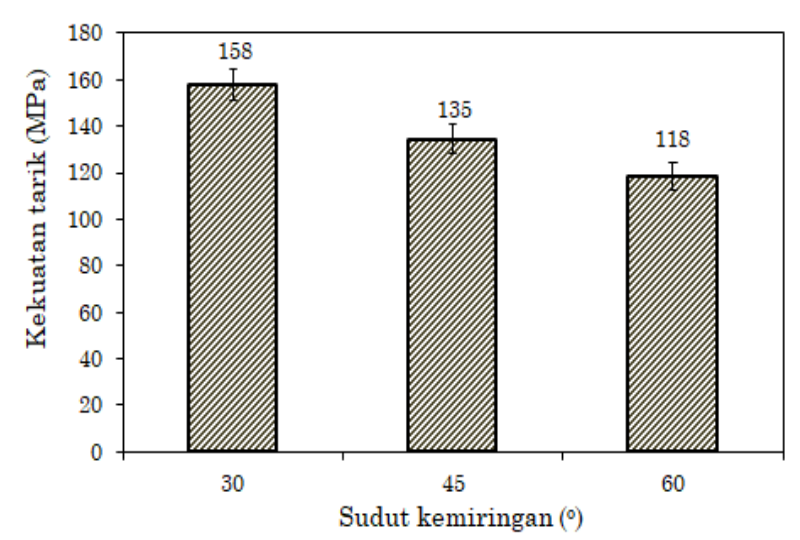

Gambar 7. Hubungan antara kemiringan cooling slope terhadap kekuatan tarik bahan re-casted Aluminium tipe A356.

Hasil pengujian tarik ini juga diperoleh hubungan antara tegangan dan regangan, seperti diperlihatkan pada gambar 8. Gambar 8 memperlihatkan tiga jenis grafik untuk tiga kondisi penuangan A356 dengan kemiringan yang berbeda. Gambar 8a dengan kemiringan $30^{\circ}$ diperoleh tegangan tarik maksimum paling tinggi bila dibandingkan dengan dua sampel lainya. Regangan yang terjadi pada sampel tersebut juga sedikit lebih besar yaitu 3,3\%, hal ini menunjukkan sampel dengan kemiringan slope $30^{\circ}$ memiliki keuletan lebih baik dibanding sampel $60^{\circ}$ yang memiliki regangan $2,7 \%$. Namun, perbedaan keuletan hasil coran kedua sampel A356 tersebut tidak berbeda jauh, dimana kekuatan yield keduanya berkisar pada $\pm 100 \mathrm{MPa}$. Hal ini juga dapat dilihat pada bentuk patahan kedua sampel uji tarik untuk kemiringan 30 dan $60^{\circ}$ seperti diperlihatkan pada gambar 9. Kedua sampel memperlihatkan profil patahan cenderung ke patah getas, dimana permukaan patahan yang rata, cerah dan tidak berserabut merupakan beberapa ciri dari patah getas. Bentuk patah getas ini berkesesuain dengan besar regangan bahan yang diperoleh dari hasil pengujian hanya berkisar $2,1 \%$ dan $3,1 \%$. Lebih lanjut, bahan alumunium yang diproduksi dengan menggunakan metode pengecoran konvensional biasanya memiliki keuletan yang lebih rendah dibanding dengan teknik produksi jenis lain seperti thermomechanical treatment. Keuletan yang rendah pada hasil coran dapat ditingkatkan dengan berbagai cara diantaranya melalui perbaikan sistem pengecoran dan perlakuan lebih lanjut.

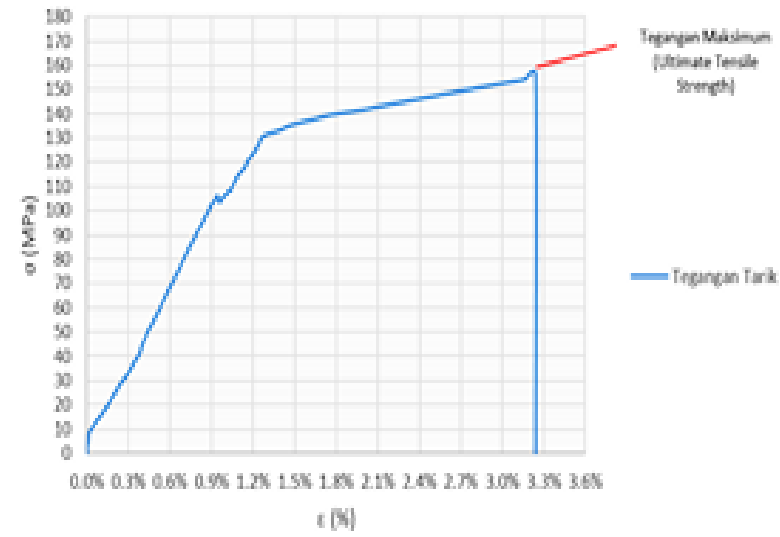

(a)

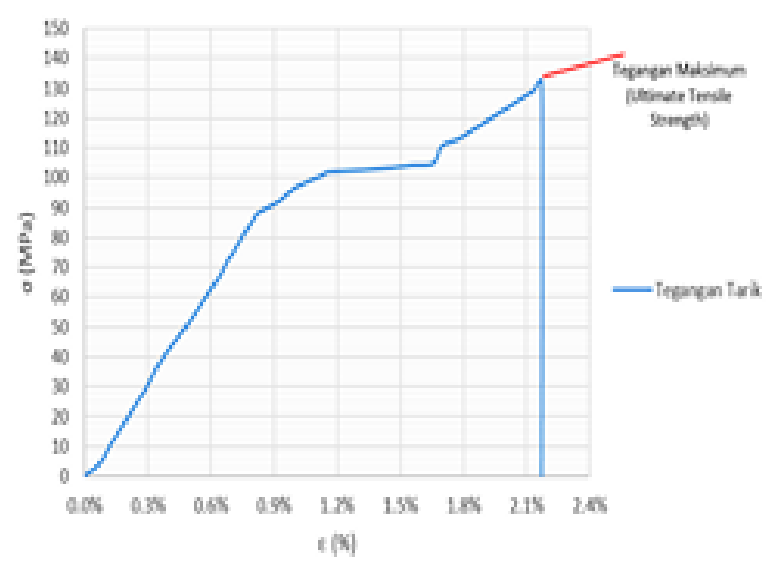

(b)

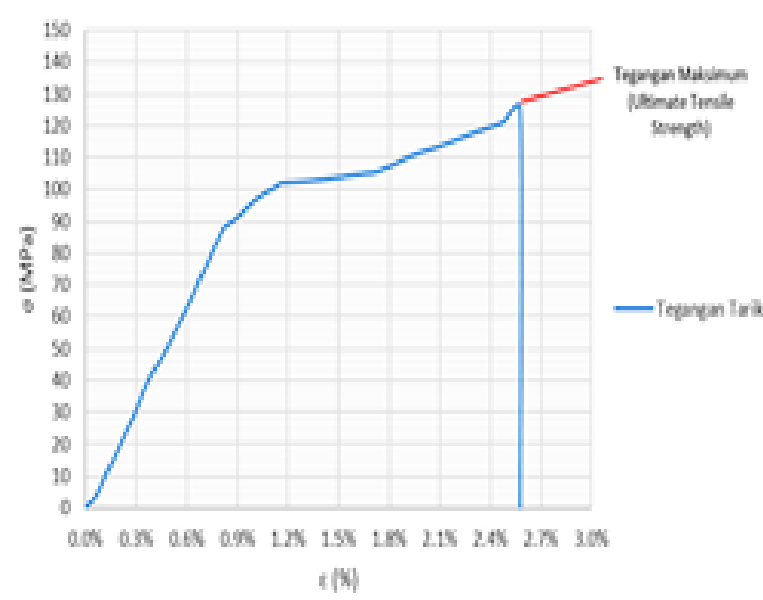

(c)

Gambar 8. Grafik hubungan tegangan dan regangan Alumunium re-casted untuk berbagai variasi sudut cooling slope: (a) $30^{\circ}$, (b) $45^{\circ}$ dan (c) $60^{\circ}$ 

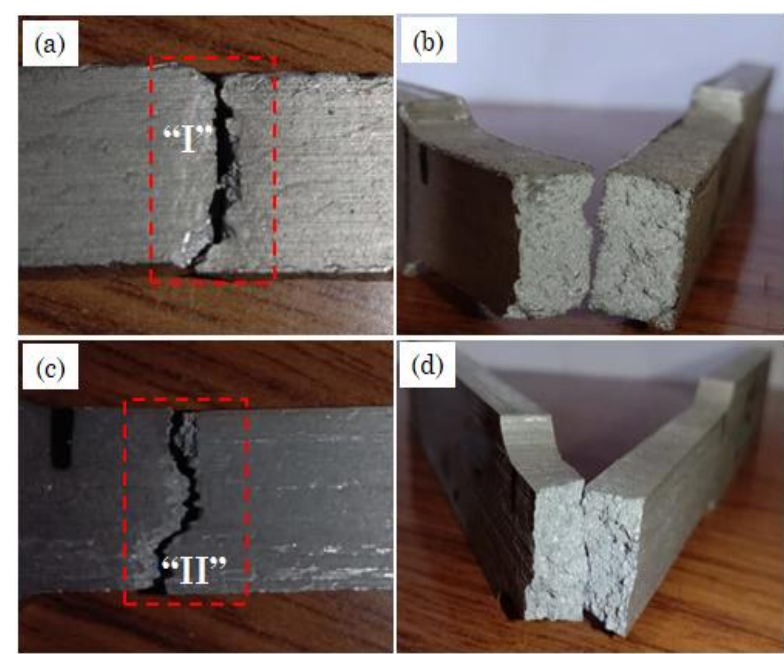

(d)

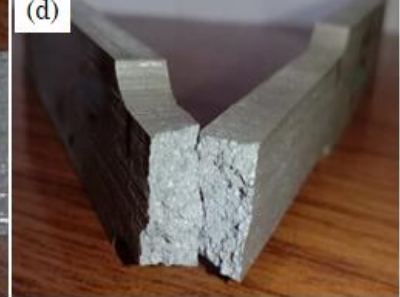

Gambar 9. Bentuk patahan sampel uji tarik dengan sudut cooling slope: (a-b) $30^{\circ}$ dan (c-d) $60 \mathrm{o}$

\section{KESIMPULAN}

Berdasarkan hasil pengujian yang telah dilakukan maka beberapa poin kesimpulan sebagai berikut:

1. Hasil pengujian fisis dan mekanis secara jelas memperlihatkan bahwa penerapan cooling slope pada pengecoran ulang A356 yang produksi PT. Inalum dipengaruhi oleh kemiringan pelat saat penuangan.

2. Mikostruktur sampel alumunium A356 terdiri primary $\mathrm{Al}$ dan partikel silikon yang terlihat sebagai butir berwarna cerah dan partikel berwarna gelap.

3. Ukuran butir lebih halus diperoleh pada sampel dengan sudut cooling slope $30^{\circ}$ dan sebaliknya butir lebih besar pada paduan A356 as cast.

4. Kekerasan tertinggi 62 BHN diperoleh pada sudut kemiringan $30^{\circ}$ dan terendah pada slope $60^{\circ}$ dengan $56,30 \mathrm{BHN}$.

5. Laju keausan yang paling rendah diperoleh pada sudut cooling slope $30^{\circ}$ yaitu $1,44 \mathrm{~mm}^{3} / \mathrm{s}$. Sebaliknya laju keausan terbesar diperoleh pada sudut penuangan $60^{\circ}$ sebesar $2,78 \mathrm{~mm} 3 / \mathrm{s}$.

6. Hasil pengujian tarik terbesar 157,63 MPa diperoleh pada sampel paduan Alumunium re-casted yang menggunakan cooling slope dengan sudut $30^{\circ}$.

\section{DAFTAR PUSTAKA}

[1] Fröck, H, Kappis, L.V., Reich, M., Kessler, O., 2019, "A Phenomenological M echanical Material Model for Precipitation Hardening Aluminium Alloys", Metals, 9, 1165, pp. 1-16

[2] Sajuri,Z., Selamat, N.F.M., Baghdadi, A.H., Rajabi, A., Omar, M.Z., Kokabi, A.H., Syarif, J., 2020, "Cold-Rolling Strain Hardening E ff ect on the Microstructure, Serration-Flow Behaviour and Dislocation Density of Friction Stir Welded AA5083", Metals, 10, 70, pp. 1-16.
[3] Jarfors, A.E.W., Du, A., Yu, G., Zheng, J., Wang, K., 2020, "On the Sustainable Choice of Alloying Elements for Strength of Aluminum-Based Alloys", Sustainability, 12, 1059, pp.1-12.

[4] Rana, R.S., Purohit, R., Das, S., 2012, "Reviews on the Influences of Alloying elements on the Microstructure and Mechanical Properties of Aluminum Alloys and Aluminum Alloy Composites", International Journal of Scientific and Research Publications, 2, 6, pp. 1-7.

[5] Venkatesan, J.J. S, K., Kuppan, P., Ramanujam, R., 2014, "Comparative Study of Composites Reinforced With $\mathrm{SiC}$ and $\mathrm{TiB} 2 "$, Procedia Engineering, 97, pp. 1012-1017. doi:10.1016/j. proeng.2014.12.378.

[6] Kim, G., Hong, S., Lee, M., Kim, S., Ioka, I., Kim, B., Kim, I, 2010, "Effect of Oxide Dispersion on Dendritic Grain Growth Characteristics of Cast Aluminum Alloy", Materials Transactions, 51, 10, pp. 1951-1957. doi:10.2320/matertrans.M 2010166.

[7] Xun Zhang, Y.X., Yi, Y.P., Huang, S.Q., Dong, F, 2016, "Influence of quenching cooling rate on residual stress and tensile properties of 2A14 aluminum alloy forgings", Mater. Sci. Eng. A., 674, pp. 658-665. doi:10.1016/j.msea.2016.08. 017.

[8] Dobrzański, L.A., Król, M., Tański, T., 2010, "Effect of cooling rate and aluminum contents on the $\mathrm{Mg}-\mathrm{Al}-\mathrm{Zn}$ alloys ' structure and mechanical properties", Journal of Achievements in Materials and Manufacturing Engineering, 43, 2, pp. 613-633.

[9] Zuo, Y., Li, H., Xia, M., Jiang, B., Scamans, G.M., Fan, Z., 2011, "Refining grain structure and porosity of an aluminium alloy with intensive melt shearing", Scripta Materialia, 64, pp. 209212.

[10] Ritwik, R., Prasada Rao, A.K., Dhindaw, B.K., 2013, "Low-convection-cooling slope cast AlSi7 Mg alloy: A rheological perspective", J. Mater. Eng. Perform, 22, 9, pp. 2487-2492. doi:10.1007/ s11665-013-0530-2.

[11] Zhang, L., Eskin, D.G., Miroux, A., Katgerman, L., 2016, "Formation of microstructure in Al-Si alloys under ultrasonic melt treatment", Light Met. 2012, The Minerals, Metals \& Materials Society, pp. 999-1004. doi:10.1007/978-3-31948179-1_174.

[12] El-Kady, A.M. E.Y., El-Mahallawi, I.S., Mahmoud, T.S., Attia, A., Mohanned, S.S., 2016, "Optimization of the cooling slope casting parameters for producing aa7075 wrought aluminum alloy thixotropic feedstock", Mater. Sci. an Indian J., 14, 8, pp. 279-287

[13] Saklakoğlu, N., Gencalp, S., Kasman, Ş., 2011, "The Effects of Cooling Slope Casting and Isothermal Treatment on Wear Behavior of A380 Alloy", Adv. Mater. Res. 264-265, pp. 4247. doi:10.4028/www.scientific.net/AMR.264265.42 . 
[14] Das, P., Dutta, S., Samanta, S.K., 2013, "Evaluation of primary phase morphology of cooling slope cast Al-Si-Mg alloy samples using image texture analysis", Proc. Inst. Mech. Eng. Part B J. Eng. Manuf., 227, 10, pp. 1474-1483. doi:10.1177/0954405413490162.

[15] Adss, D.M., Attia, E.A., Mahmoud, T.S., ElMahallawi, I.S., T.A. Khalifa, T.A., 2015, "Effect Of Cooling Slope Casting Parameters On The Thixotropic Microstructure Of A356 Aluminum Alloy", Aerospace Sciences \& Aviation Technology, ASAT2016.

[16] Mehmood, A., Shah, M., Sheikh, N.A., Qayyum, J.A., Khushnood, S., 2016, "Grain refinement of ASTM A356 aluminum alloy using sloping plate process through gravity die casting", Alexandria Eng. J., 55, pp. 2431-2438. doi:10.1016/j.aej. 2016.03.016.

[17] Das, P., Samanta, S.K., Venkatpathi, B.R.K., Chattopadhyay, H., Dutta, P., 2012, " Microstructural evolution of A356 Al alloy during flow along a cooling slope", Trans. Indian Inst. Met., 65, pp. 669-672. doi:10.1007/s12666-012-0208-8.

[18] Sahini,D., Mandal, A., Chakraborty, M., 2014, "Cooling Slope Casting Process of Semi-solid Aluminum Alloys: A Review", Int. J. Eng. Res. Technol., 3, pp. 269-283.

[19] Galek, T., Łączek, A., Łysiak, K., 2020, "Study of Nonmetallic Inclusions in Aluminum - Silicon Alloys", Advances in Manufacturing Science and Technology Study, 44, 1, pp. 28-31. doi:10.2478/ amst-2019-0008.

[20] He, T., Xion, Y., Guo, Z., Zhang, L., Ren, F., Volinsky, A.A., 2011, "Microstructure and Hardness of Laser Shocked Ultra-fine-grained Aluminum", J. Mater. Sci. Technol., 27(9), pp. 793-796.

[21] Das, P., Dutta, P., 2016, "Phase field modelling of microstructure evolution and ripening driven grain growth during cooling slope processing of A356 Al alloy", Comput. Mater. Sci., 125, pp. 819. doi:10.1016/j.commatsci.2016.08.022. 